\section{Mindre impetigo og mindre fusidinresistens}

\author{
Den europeiske fusidinresistente \\ impetigoklonen av gule stafylo- \\ kokkar er i minking. Det viser ein \\ ny studie frå Austevoll.
}

I starten av 2000-talet var det kraftige oppblomstringar av impetigo i dei skandinaviske landa og på dei britiske øyane. Mikrobiologiske studiar viste at impetigo på begge sider av Nordsjøen var relatert til ein ny fusidinresistent klon av gule stafylokokkar, som fekk nemninga «epidemic European fusidic acid-resistant impetigo clone» (EEFIC).

For å følgje prevalensen av infeksjonssjukdommar og endringar i bakterielle årsaksfaktorar i populasjonar er det naudsynt med studiar frå allmennpraksis. I 2001 starta kommunelegetenesta i Austevoll ein prospektiv studie av all impetigo i kommunen, $\mathrm{i}$ samarbeid med Universitetet i Bergen, Haukeland universitetssjukehus og Allmennmedisinsk forskningsenhet i Bergen (1).

Me dokumenterte epidemiske utbrot av impetigo på ettersommaren i åra 2002-04 (2). Nyleg viste me at insidensen etter den tid har vore sterkt minkande (3). Gule stafylokokkar er vanlegaste årsak til impetigo. I studien vår var stafylokokkane fusidinresistente i om lag $80 \%$ av tilfella i epidemiåra, men i berre $45 \%$ av tilfella $i$ åra 2008-09 (3). Dei to siste åra av studien gjorde me også molekylære undersøkingar. EEFIC var generelt i sterk minking som bakteriologisk årsak til impetigo, men var oftast årsak når gule stafylokokkar viste fusidinresistens.

\section{Sverre Rørtveit}

sverre.rortveit@aknett.net

Kommunelegetenesta i Austevoll

Bekkjarvik legekontor

\section{Litteratur}

1. Rørtveit S, Rørtveit G. Epidemi av bulløs impetigo i Austevoll kommune år 2002. Tidsskr Nor Lægeforen 2003. 123: 2557-60.

2. Rørtveit S, Rørtveit G. Impetigo in epidemic and non-epidemic phases: an incidence study over 41/ 2 years in a general population. $\mathrm{Br} \mathrm{J}$ Dermatol 2007; 157: $100-5$.

3. Rørtveit S, Skutlaberg DH, Langeland $\mathrm{N}$ et al. Impetigo in a population over 8.5 years: incidence, fusidic acid resistance and molecular characteristics. J Antimicrob Chemother 2011; doi: 10.1093/ $\mathrm{jac} / \mathrm{dkr} 102$.

\title{
Endringer i resistens hos Salmonella typhi
}

\author{
Nyere studier viser at $f \varnothing l s o m h e t e n$ for tradisjonelle antibiotika hos \\ Salmonella typhi har økt igjen.
}

Tyfoidfeber er fremdeles endemisk i mange utviklingsland, med estimater på om lag 20 millioner tilfeller årlig, hvorav $90 \%$ forekommer i Sørøst-Asia. Salmonella typhi smitter fekalt-oralt via vann og mat, men bakterien gir gjerne en systemisk infeksjon og symptombildet kan være svært variabelt (1).

Tradisjonelt har førstelinjebehandlingen vært kloramfenikol, ampicillin eller trimetoprim-sulfa. Siden 1990-årene har økende resistens vært et problem, hvilket har ført til at fluorokinoloner er blitt mer brukt. Dette har gitt nedsatt følsomhet også for fluorokinoloner, slik at kefalosporiner er blitt førstevalget ved multiresistent $\mathrm{S}$ typhi mange steder. En studie av $128 \mathrm{~S}$ typhi-isolater fra India viser imidlertid at følsomheten for hver av de tradisjonelle antibiotika har økt til ca. $95 \%$ av stammene. Dette viser viktigheten av rutinemessig resistensbestemmelse og selektiv antibiotikabruk, også ved tyfoidfeber (2).

Slike resistensmønstre kan dog ikke nødvendigvis overføres til andre geografiske områder. I en egyptisk studie var hhv. $35 \%$ og $40 \%$ av stammene resistente mot ampicillin og trimetoprim-sulfa. Det var imidlertid kun $8 \%$ resistens mot kloramfenikol. Forfatterne randomiserte 27 pasienter til behandling med kloramfenikol og 25 pasienter til behandling med ceftriakson. Alle ble friske innen sju dager, men forløpet var kortere ved ceftriaksonbehandling $(3,3 \mathrm{~d} \pm 1,2$ dager mot $5,8 d \pm 1,2 d$ l). Forfatterne konkluderer med at ceftriakson bør være førstevalget ved alvorlig tyfoidfeber, men at kloramfenikol kan være på vei tilbake som behandlingsalternativ (3).

\section{Kristoffer Brodwall}

kristoffer.brodwall@gmail.com

Barneklinikken

Haukeland universitetssykehus

\footnotetext{
Litteratur

1. Rahman AKMM, Ahmad M, Begum RS et al. Typhoid fever in children - an update. J Dhaka Med Coll 2010; 19: 135-43

2. Kumar Y, Sharma A, Mani KR. Re-emergence of susceptibility to conventionally used drugs among strains of Salmonella typhi in central West India. J Infect Dev Ctries 2011; 5: 227-30.

3. Hammad OM, Hifnawy T, Omran D et al. Ceftriaxone versus chloramphenicol for treatment of acute typ-
} hoid fever. Life Science Journal 2011; 8: 100-5.

\section{Interessekonflikter oppgis ikke i metaanalyser}

\author{
I metaanalyser av effekten av \\ farmakologisk behandling oppgis \\ kun unntaksvis forfatternes \\ interessekonflikter. Dette viser \\ en studie publisert i JAMA.
}

Metaanalyser av randomiserte kliniske studier får ofte stor betydning for medisinsk praksis, særlig når de publiseres i de mest prestisjefylte fagtidsskriftene. Likevel forventes det oftest ikke at det i metaanalysene redegjøres for eventuelle interessekonflikter $\mathrm{i}$ originalarbeidene som ligger til grunn.

I en ny studie gjennomgikk forfatterne metaanalyser fra generelle medisinske tidsskrifter med impaktfaktor $>10$, fra sentrale spesialtidsskrifter innen fem medisinske spesialiteter med høyt legemiddelsalg og fra Cochrane-databasen (1). De totalt 29 metaanalysene inkluderte til sammen 509 randomiserte, kontrollerte studier. I kun to av de 29 (7\%) var finansieringskildene til de inkluderte studiene oppgitt, og ikke i noen var det opplyst om andre typer interessekonflikter knyttet til farmasøytisk industri. Av de 509 inkluderte enkeltstudiene var det i 318 beskrevet slike interessekonflikter, i 219 av disse gjaldt det industrifinansiering.

- Det finnes en stor og omfattende forskningslitteratur som entydig viser at interessekonflikter i form av relasjoner til farmasøytisk industri gir skjevheter i tolking og rapportering av resultater, sier Lars Slørdal, professor i farmakologi ved Norges teknisk-naturvitenskapelige universitet.

- Dette kan underminere både tilliten pasientene har til oss og vår egen tillit til måten faget vårt utøves på. Det må settes tydelig og permanent søkelys på viktigheten av at det i forskningsrapporter gjøres rede for interessekonflikter. Alle slike relasjoner må rapporteres sannferdig og detaljert, og en evaluering av effekten av industrielt samrøre bør i fremtiden høre med blant komponentene som skal inngå i metaanalyser, sier Slørdal.

\footnotetext{
Are Brean

are.brean@legeforeningen.no

Tidsskriftet

Litteratur

1. Roseman M, Millette K, Bero LA et al. Reporting of conflicts of interest in meta-analyses of trials of pharmacological treatments. JAMA 2011: 305: $1008-17$.
} 